\title{
5 \\ A Link to Humanity: \\ Judaism as Nation and Universal Religion
}

Scholars have long pondered the presence — or absence — of political ideas in Jewish thought in the Middle Ages and the Renaissance. On the one hand, some argue that Jewish thought essentially became disengaged from the political sphere during that period in both the Muslim and the Christian worlds, for the obvious reason that political reflections were irrelevant in the absence of either a state or an autonomous political life. On the other hand, many agree with Leo Strauss that, unlike Christian thought but like Muslim thought, Jewish thought is founded on a religious tradition that does not differentiate between the earthly and celestial spheres, but instead incorporates the political into the theological. Proponents of this second position assert that Jewish political thought is not to be found in specifically political texts - as it is in the Greco-Roman-Christian tradition - but lies scattered in other types of documents, such as legal or even theological texts.

Abraham Melamed sums up this approach in a well-documented and thought-provoking article, "Is there a Jewish Political Thought? The Medieval Case Reconsidered."1 Noting that there is no Jewish political thought in the traditional sense of the phrase, Melamed proposes to expand or alter the sphere of "political thought" in the Jewish tradition to other literary genres, such as judicial responsa or moral literature. In this sense, Jewish culture did produce political thought, although not by the standards of the GrecoRoman-Christian canons from which this intellectual discipline derives in the Western tradition.

Melamed's argument is broadly valid. And yet, even if we were to skip over well-known cases - such as that of Maimonides, who had a distinct influence over the Christian world ${ }^{2}$ - in order to focus on the so-called modern era, it would still be possible to find instances of political thought in the "traditional" sense of the phrase in several Jewish works.

Unsurprisingly, these writings are to be found in the textual production of the most intellectually advanced Jewish community of the sixteenth and seventeenth centuries: the Italian Jewish community, which had assimilated 
and had, through contact with the culture of the Italian Renaissance and post-Renaissance, developed disciplines that were neglected or completely unknown (and in some cases condemned) by Jews of other regions. These disciplines included rhetoric, historiography, philology, science, and profane poetry, which thrived with extraordinary intensity and continuity in that community.

Political expression flourished alongside these disciplines, although its development was sporadic rather than systematic. Instead of tackling themes typical of political thought, it consisted for the most part of observations on the highly "apolitical" condition of the Jews at the time. Although a few authors effectively turned to traditional political categories, they either adopted a negative stance, remarking on the present non-applicability of these categories to their existence, or focused on portents of change in the condition of the Jewish people, arguing that the Jews can and must reclaim their political identity, just like other peoples. This involved variants on familiar Jewish themes hinging on their relationship with others, and on the tension between exile and the prospect of reconstruction. Yet the rhetoric these authors deployed departs significantly from tradition: in their writings, they underlined the national character of the Jewish religion, to the detriment of its theological importance. In this way, these Italian Jewish authors made political expression in the traditional sense of the phrase ${ }^{3}$ possible for the Jews.

\section{"A nation incapable, in its present condition, of any political government": Simone Luzzatto's Discourse Concerning the Condition of the Jews}

As we saw in the previous chapter, in Discourse Concerning the Condition of the Jews, published in $1638,{ }^{4}$ the Venician Rabbi Simone Luzzatto gave what one might call an anthropologic, rather than apologetic, account of the condition of his coreligionists, ${ }^{5}$ adopting the perspective of an external observer. The result is a precise and at times impious description of the rites, beliefs, and behaviors of contemporary Jews, based on categories borrowed from external assessments of the Jewish tradition. Thus, the account Luzzatto gives of the Jewish intellectuals of his time is founded on notions drawn from Greco-Roman literary and philosophical culture. For instance, he resorts to the notions of the "particular" and the "universal" in order to 
evoke their political predicament. Although central to his argument, these notions have no equivalent in Hebrew, at least not in the sense Luzzatto intended.

Indeed, the very fact that this Discourse was written in Italian - rather than in Hebrew as was customary for Jewish writers - is noteworthy, because it induced him to use categories borrowed from the culture of the "Other." Although it is true that addressing the city authorities required him to write in Italian, Luzzatto nevertheless seems to have been completely at ease developing an "objective" argument in a language that was in a sense "extraneous" to the Jewish reality. As the Jewish rabbi's only other published text, the philosophical treatise Socrate ovvero dell'humano sapere (Venice, 1651), ${ }^{6}$ was also written in Italian, it seems that he participated in the general propensity of the Italian Jewish community of that period to adopt the Italian language. ${ }^{7}$

The following is the introduction Luzzatto gives in his Discourse to his account of the rites and customs of the Jews at the time, which was briefly discussed above:

If [...] it is difficult to define the particular customs of an individual, how can one determine those of an entire Nation? This is especially problematic in the case of the Jewish people, who are so dispersed all over the world that it is impossible to speak about them with any certainty or decisiveness. Across the universe, just as the waters of a river flowing through a village receive impressions from the many lands it runs through, the members of the Jewish people living in other nations have acquired a range of different customs. In the same way that those who live in Venice have very different ways than those from Constantinople, the latter diverge from those of Damascus and Cagliari, and all of them differ from the Germans and the Poles. Yet, if anyone wished to inquire after their universal customs, it might be said that the soul of their Nation is so debased and weakened as to be incapable of any form of political governance while they are in their current state. So preoccupied are they with their particular predicament that they fail to take any interest in the universal and are parsimonious to the point of meanness. They are great admirers of ancient times but poor observers of current affairs, and many of them are also bad-mannered and little versed in the doctrines and knowledge of languages. Others also say that they are dutiful, indeed 
scrupulous, in their observance of their Laws. Whatever their faults may be, they nevertheless also exhibit many noteworthy qualities. They are steady and wonderfully unwavering in their belief in, and observance of, their Religion. The dogmas of their Faith have remained uniform over the course of the 1,550 years they have been scattered all over the world. They are admirably constant-if not always in the presence of danger, then at least in the face of adversity. They have a unique understanding of the Sacred Writings and their interpretation. They show human charity and hospitality to all the members of their Nation, whether or not these are foreign to them: thus, the Persian Jew empathizes with the suffering of the Italian, and distance does not dissolve their bond, or affect the uniformity of their Religion.

The account Luzzatto gives of exile in this excerpt is significant. Describing the Jews journeying across different peoples and absorbing the various "customs" and "ways" of those with whom they come in contact, he almost entirely neglects to mention the suffering associated with exile, which is a commonplace in Jewish literature. Similarly, the essentially positive slant he gives to the image of the river flowing through different lands contrasts with the way that metaphor is usually deployed in Jewish Italian works. ${ }^{8}$

Although Luzzatto's remarks are based on objective observations, he also doubtless seeks to justify his thesis that his community is harmless when, a few pages later, he emphasizes the political passivity of the Jews of his time. ${ }^{9}$ Even under the most trying circumstances, as in 1492 Spain, they never dared rebel against authority:

... Since proselytizing is not a Jewish precept, they never had any thought of universally raising the issue of their People, and believed that everything that happened to them was caused by a superior cause rather than human action. In the time of King Ferdinand and Queen Isabel, as a great number of them - nearly half a million - resided in Castilia and other nearby realms, and were forced to convert or go into exile, 300,000 of them refused to convert to Christianity. Yet none of them dared to rise resolutely against that miserable banishment: instead, they scattered all over the world. This shows that contemporary Jewish customs incline them to subjection and obedience towards their princes. (P. 57) 
However, Luzzatto does not merely set out to make unflattering observations. True, the docility which makes the Jews easy to subjugate and prone to focus on their particular sphere, as opposed to the "universal"-wider wordly events - is the consequence of their fatalism; nonetheless passivity does not completely pervade their souls. Their focus on the "particular" does not entail isolation in petty egoism. Although the author proceeds to assert that it is true that Jews generally show little interest in the scientific and literary production of the wider culture, preferring to concentrate on studying their own texts, they nevertheless know how to be open to others. According to Luzzatto, this capacity to reach out is dictated by their very religion, which has universal dimensions that are not at odds with the particularity of the Law. According to their religion, men have a common origin because they share the same father, Adam. Indeed, the injunction to respect other religions (except those that preach appalling and unnatural behavior) prohibits offending their divinities. The "particular beliefs" of the Jews do not exempt them from having a "link to humanity" and entering into a "reciprocal friendship" with humankind, as there are "various degrees of connection between men"; therefore

... Together with those who are alien to their religion, the Jews belong and are bound to that human community which observes the precepts of natural morality and has some knowledge of a superior cause. (P. 52r)

At the time, it was widely believed that the humanity of Men resided in acknowledging the existence of a superior cause and sharing in the precepts of natural morality. Beyond that, according to the Venetian rabbi, everything is merely impiety and superstition, which Jewish Law has always tried to eradicate. Indeed, this is especially true of superstition, as this "abuse,... or excrement of the true Religion and legitimate cult of God" is particularly insidious and underhanded. In sum, for Luzzatto, at the heart of "Judaism" lies a desire

... to eradicate superstition, because the orderly succession of causes, and even the anatomy of the merest creature, are good reasons to believe, and refute Atheism. (p. 66r)

In other words, atheism is at odds with the proper deployment of reason and with the Jewish religion-inasmuch as proper religious behavior 
conforms to reason, is at odds with superstition and immorality (as demonstrated by regular biblical injunctions against idolatry and its rites) and is universal.

Luzzatto's position and ideological strategy are clear: turning to the Venetian authorities, he wishes to present the Jews as loyal subjects, too weakened to be capable of vain political ambitions, and, therefore, rebellion. At the same time, Luzzatto's account suggests that even though their culture is only concerned with essentially religious and apolitical matters the Jews are not exclusivist; instead, they consider that all those whose religion and ethics conform to reason (even when they are not rooted in it) share in the same humanity, whatever their rites. Even as he recognizes the material and political decadence of the Jews and their disinterest in the universal, he vindicates their religion, which sets out to uncover superstition. However, the qualities of this religion do not seem to reside in its exclusive election so much as in its universal dimension. The flip side of the inadequacy of the Jews in the realm of the political universal is their aptitude to achieve a religious universal.

Even though one must not forget that Luzzatto's Discourse is apologetic in nature, the sheer breadth and rigor of his argumentation, together with the fact that it echoes positions he adopted in other contexts, ${ }^{10}$ suggest that it expresses the Venetian rabbi's true position.

During the so-called first "period of the ghetto," during which Luzzatto writes, considerable progress had already been made to create common cultural ground between Jews and Christians, in order that they might understand each other. This common ground resided in a natural morality and a theistically-inspired religiosity which need not be confessional but were resolutely at odds with atheism; it was also founded in the beginning of their historiography ${ }^{11}$ and in an embryonic form of religious anthropology that shied away from theological polemics. The Venetian rabbi presents the Jews as a nation on historical-anthropological grounds: although decadence has made them "incapable in their present condition of any political state," they nevertheless constitute a nation. ${ }^{12}$ This nation owes its unity to the strong chains of religion: it deploys what little secular culture it has to religious ends, in order to achieve a better understanding of the scriptures. In the past, it excelled at the art of war, literature, and the sciences; but as a result of exile, not only have its members become weakened, but "every light of knowledge is almost extinguished in them and any splendor of erudition almost obscured" (p. 74a). 
Yet, "not every spark was extinguished" (75b) during its long exile, and one may speak of its "literary occupations" despite its limited engagement with the "human disciplines."

It may seem rather surprising that the preeminent rabbi of the prestigious Venetian Jewish community should present Jewish exilic culture as crippled and limited. Although this idea is not shocking in itself, as evocations of intellectual decadence were in fact typical of Jewish historical accounts, it is startling to come across it outside of a religious context bemoaning the collective sins of the Jews and lamenting their decreasing observation of religious rites and declining interest in studying the Torah. In this text, history is kept separate from theology, confirming - as Melamed has shown ${ }^{13}$ - that Luzzatto was well-acquainted with the writings of Machiavelli, which were well-known despite being banned.

In the Discourse Concerning the Condition of the Jews, Luzzatto does not offer a way to transcend these limits: however, in some of his rare texts in Hebrew he praises and encourages the Jews' receptivity to the sciences and contrasts it to "pious ignorance," probably referring to the kabbalists, whose popularity he denounced during those same years. ${ }^{14}$

The belief that Judaism could be loyal to its traditions while being invested in the general progress of the sciences, open to humanity and respectful of differences, actively engaged in the fight against superstition and keen to prove the vanity of atheism, and cherished by all rational ethical men who place their faith in a Supreme Being was held by the Venetian rabbi and formed a coherent scheme, which might be termed "modern." 15

The celebrated third chapter of Spinoza's Tractatus Theologico-politicus, published in 1670 (that is, thirty years after the Discourse) did not disagree, even if it adopted a different tone. Speaking on the "Vocation of the Hebrews," the Dutch philosopher insisted on the political character of this vocation, since "the Lord is not so nigh to any other nation as $\mathrm{He}$ is to the Jews [...] for in respect of intellect and virtue [...] God was [...] equally gracious to all." 16 Thus, according to Spinoza, the Jews did constitute a nation with an honorable political and military past which was currently cemented by established religious rites, although it lacked the particular qualities of prophecy, that is, a proximity to God and an understanding of his decrees. These traits led Spinoza to declare that one day the Jews would perhaps rebuild their state, "if the foundations of their religion have not emasculated their minds," 17 echoing Luzzatto's evocation of the "debased 
and weakened" soul of the Jews "in their current state"- that is, under the conditions of exile.

These aspects of Luzzatto's position-his notion that the Jews form a nation and that this has no theological implications for their election, together with his vision of the Jewish religion as neither closed nor exclusive, but on the contrary open to humanity - had, in truth, already been developed by other Jewish Italian thinkers before him.

We have already analyzed the "political" sections of Avraham Portaleone's Shiltey ha-Gibborym (1612), in which the Mantuan doctor imagines a Jewish nation "capable of having a universal dimension," to quote Luzzatto; that is, a nation possessing all the social strata of a "normal" society, from farmers to craftsmen and a civil elite, as well as its own army. ${ }^{18}$

As Luzzzatto would recall a few decades later, the call Portaleone made to the Jews - through the mouthpiece of a priest in charge of the war-to acquire a theoretical and practical knowledge of the art of war sounded like an attempt to bring them out of their passivity:

You too must do your part. Do not gaze at the sky like a dim-witted idler, like a fool counting the stars; so numerous that they cannot be counted [...]. It falls to you, O blessed by the Lord, it is up to you to take up arms and kill those who hate you, Ismael, Moab and the converts, to vindicate yourselves from your enemies, who are rising to destroy you. (36v)

These lines invite a few remarks. The first is that the Jewish author shows a very modern contempt for "idle contemplation," which itself evokes the way medieval science was perceived at the end of the Renaissance. In this sense, Portaleone belongs to a small group of resolutely "modern" Jewish Italian scientists, along with the likes of the mathematician and astronomer Yosef Shelomo Delmedigo (1591-1655) and Simone Luzzatto himself, who had a reputation as a good mathematician. ${ }^{19}$

Portaleone's helpless call to arms evokes Luzzatto's account of the weakened Jewish people. Indeed, although one of these accounts is utopian and the other objective, it is worth noting that even an author as tormented and as contradictory as Portaleone - he was at once an objective scientist and a devout follower of a traditional and partly kabbalistic pietas - voiced the idea that the Jews formed a nation: a nation that had lost touch with both the sciences and the habit of action, but could rediscover both. 


\section{Abraham, the Common Father: The Universalism of David de' Pomi.}

Simone Luzzatto's conception of Judaism - the notion that it is an open and universal religion - had also already been advanced fifty years earlier by another Jewish author, David de' Pomi, in a Latin text titled De medico hebraeo enarratio apologica (An Apologetic Discourse on the Jewish Doctor), published in Venice in 1588. De' Pomi's objective was to defend the probity of doctors in general, and of Jewish doctors in particular, as Christians were suspicious of them and reluctant to engage their services, fearing that they did not have their patients' best interests at heart. In 1584, Pope Gregory XIII had forbidden Jewish physicians to heal Christian patients. However, de' Pomi's book quickly moves from this question to the global relationship between Judaism and Christianity. Like any Jewish author wishing to enter into a dialogue with Christians without renouncing his own particularity, de' Pomi embraces a pluralistic vision and begins by acknowledging that men are naturally diverse "in religion, grade, and dignity." ${ }^{20} \mathrm{He}$ then follows a two-pronged strategy: first, he demonstrates the beauty and humanity of the Jewish religion, quoting a series of ancient Jewish maxims of universal import (taken from the mishnaic treatise Pirkey Avoth); and second, he attempts to show how religious diversity need not impede true friendship. Rather "audaciously," as he himself admits, ${ }^{21}$ the author brings to the fore the fundamental affinity between Judaism and Christianity, illustrating it by citing numerous passages from the Gospels and some carefully selected letters by St. Paul. ${ }^{22}$

De' Pomi describes the foundations of an Abrahamic religion encompassing the Jews, the Christians, and the Muslims (although he has some reservations about the latter, probably given the situation in Venice during the Turkish-Venetian war). Abraham, their common father,

possessed the necessary science to attain the greatest virtue: he was exemplary among men for his faith, temperance, honesty, innocence, and piety. ${ }^{23}$

Their real common enemies are the idolaters, those who deny the true cult of God; however, in Europe - in Christian countries, that is - this type of enemy does not exist, and has never existed. In sum, Christians and Jews are brothers,

but that is not enough, because all men are brothers, except those Nations rejected by God for one and only reason, their cult of idolatry. ${ }^{24}$ 
On the one hand, the Jewish doctor feels compelled to show that the Mosaic Law believes that the enemies of the Jews can be counted precisely and consist of those peoples who dissuaded the Jews from their divine cult and lived in the Jews' promised land, neither of which applies to the Christians. Indeed, if it is true - as Josephus Flavius asserts - that the Romans, who went on to become Christians, were descended from the Edomites, then the following verse from Deuteronomy (23:3) may apply to them: "Thou shalt not abhor an Edomite; for he is thy brother." ${ }^{25}$ On the other hand, de' Pomi lists several of the repeated references the New Testament makes to the Jewishness of Jesus and Paul, fully endorsing it. He concludes that not only are these two religions not at odds, but the chain of "carnal and spiritual"26 affinities linking them far outweighs their differences, which in the end are minimal. ${ }^{27}$ Jews and Christians are God's witnesses, and spread moral and religious virtues ${ }^{28}$ while also pursuing indulgence and charity. ${ }^{29}$

Thus, according to de' Pomi, there is a Judeo-Christian (and partially Muslim) civilization founded on the cult of a common God, which does not preclude particular attitudinal differences. Although one may object that this book is a work of apologetics, much like Luzzatto's Discourse, the Jewish doctor's previous works nevertheless seem to suggest that his ecumenism was heartfelt. In particular, his Discorso intorno a l'humana miseria, e sopra'l modo di fuggirla ${ }^{30}$ - a text on ethics published alongside an Italian version of the Ecclesiastes ${ }^{31}$ —is saturated with a non-confessional religiosity: exclusively basing himself on the Book of Ecclesiastes, which he considers to be a moral treatise the true meaning of which was as misunderstood by the Jews as it was by the Christians, de' Pomi warns his readers against pessimism, skepticism, and excess. In his later Enarratio apologica, de' Pomi includes a series of non-confessional rabbinic maxims of universal moral import in the Appendix ("Sciences of the Ancient Jews"), in order to confirm the Jews' capacity to rise to ethical universality.

Between the end of the sixteenth and the first half of the seventeenth centuries, Italian Jews thus variously began to conceive of themselves as forming a nation materially and intellectually weakened by exile: their constant references to their political and military past — as opposed to their religious election-reinforce this impression further. Although particular rituals and beliefs cemented this nation, its religion fundamentally encompassed humanity as a whole, since it considered Adam, or Abraham, the common father of all men, or believers, whatever their individual confessions. 
The Jews thus had the right to re-integrate into the community of nations, rediscovering the path to social - and perhaps even political-normalcy, and aspiring to the dignity owed to all those who shared basic moral and religious precepts.

Leone Modena naturally comes to mind in this context. Just like Luzzatto, Modena gave an objective account of "Jewish rites" in his Historia de' riti ebraici, ${ }^{32}$ later confirming the anthropological - indeed in some ways almost post-theological-vision he develops in other works. ${ }^{33}$ The Venetian rabbi encouraged the Jews to translate the Bible into literary Tuscan, rather than medieval Judeo-Italian, ${ }^{34}$ and also probably covertly tried to reform the Jewish religion by omitting some of its more "particularistic" rites and describing its characteristics in biblical, rather than rabbinic, terms. ${ }^{35}$

\section{The Return of Exclusivism}

This was only one strand of the Jewish Italian culture of the period. An entirely different current developed in parallel, reaching its peak at the beginning of the eighteenth century.

We have already evoked the significant chapter of Jewish intellectual history that corresponds to the spread of kabbalistic sensibility in the second half of the sixteenth century, in the wake of the works and teachings of figures such as Mosheh Cordovero and Yitzhaq Luria, in Safed and Galilea. As the study of Kabbalah took off, an esoteric doctrine which had been the preserve of a few initiates progressively became the shared heritage of all believers, including the most unsophisticated. ${ }^{36}$ Naturally, this new sensibility called for collections of the new interpretations of Kabbalah. Even as early as 1558 , the publication of the first print edition of the Zohar and other important kabbalistic writings was not opposed by anti-kabbalists so much as by those rabbis who, although they acknowledged Kabbalah as possessing supreme knowledge, feared that its dissemination would require reading rather unorthodox works, as well as making them vulnerable to a fresh outbreak of ecclesiastical censorship at a time when Italian Jews were still smarting from the burning of the Talmud decreed by the Church a few years previously. ${ }^{37}$

It is not possible to delineate the contrast between old and new intellectual attitudes here. Suffice it to say that Kabbalah brought to the fore the particularity and superiority of the Jewish people, grounding these attributes 
in the belief that they were the depository of the most profound truths about God and the world, which teachers had transmitted from one generation to the next, starting with Moses, who received them from God Himself.

Kabbalah opened a rift between the Jews - who were not only the depositories of these truths but also could act upon the divine world through the mediation of certain practices - and non-Jews; moreover, Kabbalah was at odds with philosophy and the sciences, as any revealed and true doctrine may be when dealing with human and uncertain knowledge.

Whether they were kabbalists or the proponents of a scientific, protonationalistic and universalistic spirit, Italian Jews were at the vanguard of the Jewish world: they were the first to understand and study the teachings of the masters of Galilee, which they also disseminated by printing them. In sum, Italy was where the Land of Israel met the rest of the Jewish worldboth Sephardi and Ashkenazi - which was itself rapidly conquered by this devotion and love for the study and practice of Kabbalah. Although the near hegemony of Kabbalah lasted for almost two centuries, it is difficult to explain how the doctrine was able to become so widespread so rapidly in so "modern" a state as Italy. The religious and epistemological crisis which made space for the Reform and for so-called "post-Tridentine" Catholicism in the Christian world of the late Renaissance probably generated a spiritual void in the Jewish sphere that modernists such as Simone Luzzatto were unable to fill. There are echoes of a futile resistance to Kabbalah - to "this" Kabbalah - from Luzzatto himself, as well as from other rabbis of the period, such as Leone Modena. ${ }^{38}$ However, despite not being in short supply, the opponents of Kabbalah could clearly not express themselves publicly: their interventions were anonymous, and they had difficulty publishing their works, which often remained in manuscript form. Indeed, they were sometimes even forced into voluntary exile from their native city, as happened to the poet Ya'aqov Francés in the wake of the outcry caused by his rationalist verse, even though he opposed Sabbateanism, rather than Kabbalah in general. ${ }^{39}$

The spread through Italy of a number of complex, suggestive, and totalizing doctrines bearing some formal resemblance to science but at odds with it and denouncing its futility - if not outright harmfulnesss - suggests that, despite the fact that the most modern Jewish culture was evolving in that region, it was also in a sense being "orientalized" by ideas coming from the Land of Israel. 
Italy had several great representatives of Kabbalah at the beginning of the eighteenth century, yet, so problematic was their relationship with science, philosophy, and the belief in Jewish exclusivity which marked their vision of the Other that they were on their way out. Their followers would essentially be confined to Eastern Europe, while in Italy Jews would reestablish contact with "the letters and the sciences" and start collaborating again with their Christian fellow citizens, allowing for the re-emergence of the rationalists' universalist stance. Although one may wonder to what extent this new-found harmony made them lose their particularity, as they merged with the common culture of so-called "modernity," what is certain is that the notion that Judaism constitutes a nation started to disappear as Italian Jews increasingly began to see themselves as the Jewish citizens of the Italian nation. 